УДК 796.411:159.9:613.8

\title{
ВПЛИВ ЗАНЯТЬ КРОСФІТОМ НА ПСИХІЧНИЙ СТАН ТА ЯКІСТЬ ЖИТТЯ МОЛОДІ
}

\author{
Юлія Павлова ${ }^{1}$, Олена Заставська ${ }^{2}$ \\ ${ }^{1}$ Львівський державний університет фізичної культури імені Івана Боберського, м. Львів, Україна, \\ pavlova.j.o@gmail.com; \\ ${ }^{2}$ Спортивний клуб «Олімп», м. Львів, Україна
}

https://doi.org/10.29038/2220-7481-2019-01-62-70

\begin{abstract}
Анотації
Aктуальність. Незважаючи на значні напрацювання, детальне вивчення біологічних, соціальних та поведінкових аспектів і значення рухової активності для психічного здоров'я людини, відкритими для розгляду й дискусії залишаються питання розуміння механізмів впливу фізичної активності на психічне здоров'я дітей та підлітків. Мета статті - оцінити вплив занять кросфітом на психічний стан і показники якості життя осіб підліткового віку. Методи. У дослідженні взяли участь 14 осіб віком 14-16 років. Тренування з кросфіту тривалістю 1 год відбувалися тричі на тиждень упродовж двох місяців. До складу тренувань входили багатофункціональні комплексні вправи переважно силової спрямованості, які учасники виконували в аеробному режимі в зоні високої інтенсивності, тривалістю не більше ніж 20 хв. Для оцінювання якості життя застосовували анкету PedsQL TM (Generic Core, український варіант для респондентів віком 13-18 років). Уявлення учасників про самого себе («Я»-концепція) вивчали за оцінкою фізичного «Я», настрою, спортивної й академічної компетентностей. Залежні між собою непараметричні вибірки порівнювали за допомогою Z-критерію Вілкоксона. Результати. Після участі у 8-тижневій програмі спостерігали зростання $(\mathrm{p}<0,01)$ рівня фізичної підготовленості за результатами виконання комплексів вправ. Середні значення всіх показників «Я»-концепції зростали після участі в програмі. Позитивну динаміку спостерігали для показників «Настрій» $(\mathrm{p}=0,09)$, «Спортивна компетентність» $(\mathrm{p}=0,09)$, «Академічна компетентність» $(\mathrm{p}=0,10)$. По завершенню програми показники якості життя зросли на 4-10 балів та перевищували значення 75 балів. Зміни спостерігали щодо показників шкал «Фізичне функціонування» (на $10 \%$, $\mathrm{p}=0,1)$, «Емоційне функціонування» (на $14 \%, \mathrm{p}=0,09$ ) i «Функціонування в школі» (на $15 \%, \mathrm{p}=0,03$ ). Висновки. Одночасно зі збільшенням рівня фізичної підготовленості, 8-тижневі тренування з кросфіту сприяли зростанню впевненості в собі, поліпшенню настрою. В учасників програми спостерігали зростання показників якості життя на $10-15 \%$.
\end{abstract}

Ключові слова: якість життя, пов'язана зі здоров'ям; психічне здоров'я, PedsQL, CrossFit, силовий фітнес, підлітки.

Юлия Павлова, Елена Заставская. Влияние занятий кросфитом на психическое состояние и качество жизни молодежи. Актуальность. Несмотря на значительные наработки, детальное изучение биологических, социальных и поведенческих аспектов и значения двигательной активности для психического здоровья человека, открытыми для рассмотрения и дискуссии остаются вопросы понимания механизмов влияния физической активности на психическое здоровье детей и подростков. Цель статьи - оценить влияние занятий кросфитом на психическое состояние и показатели качества жизни лиц подросткового возраста. Memodы. В исследовании приняли участие 14 человек в возрасте 14-16 лет. Тренировки с кросфита продолжительностью 1 час происходили три раза в неделю в течение двух месяцев. В состав тренировок входили многофункциональные комплексные упражнения, преимущественно силовой направленности, которые участники выполняли в аэробном режиме в зоне высокой интенсивности, длительностью не более чем 20 мин. Для оценки качества жизни применяли анкету PedsQL ${ }^{\mathrm{TM}}$ (Generic Core, украинский вариант для респондентов в возрасте 13-18 лет). Представление участников о самом себе («Я»-концепция) изучали по оценке физического «Я», настроения, спортивной и академической компетентности. Зависимые между собой непараметрические выборки сравнивали с помощью Z-критерия Вилкоксона. Результаты. После участия в 8 -недельной программе наблюдали рост $(\mathrm{p}<0,01)$ уровня физической подготовленности по результатам выполнения комплексов упражнений. Средние значения всех показателей «Я»-концепции росли после участия в программе. Положительную динамику наблюдали для показателей «Настроение» $(\mathrm{p}=0,09)$, «Спортивная компетентность» $(\mathrm{p}=0,09)$, «Академическая компетентность» $(\mathrm{p}=0,10)$. По завершению программы показатели качества жизни выросли на 4-10 баллов и превышали значение 75 баллов. Изменения наблюдали по показателям шкал «Физическое функционирование» (на $10 \%$, p=0,1), «Эмоциональное функционирование» (на $14 \%, \mathrm{p}=0,09)$ и «Функционирование в школе» (на $15 \%, \mathrm{p}=0,03)$. Вықбоды. Одновременно с увеличением уровня физической подготовленности 8-недельные тренировки с кросфита способствовали росту уверенности в себе, улучшению настроения. В участников программы наблюдали рост показателей качества жизни на $10-15 \%$. 
Ключевые слова: качество жизни, связанное со здоровцем; психическое здоровье, PedsQL, CrossFit, силовой фитнес, подростки.

Iuliia Pavlova, Olena Zastavska. Influence of CrossFit Training on the Mental Condition and Quality of Life of Young People. Topicality. Despite significant achievements and a detailed study of the biological, social and behavioral aspects and the importance of motor activity for a person's mental health, open to consideration and discussion remains the question of understanding the mechanisms of the influence of physical activity on the mental health of children and adolescents. The purpose was to evaluate the impact of CrossFit training on the mental status and indicators of life quality of adolescents. Methods. The study involved 14 people aged 14-16 years. CrossFit training lasted 1 hour 3 times a week for two months. The training included multifunctional complex exercises, mainly of strength orientation, which participants performed in the aerobic mode in a zone of high intensity, duration of no more than 20 minutes. The PedsQL ${ }^{\text {TM }}$ questionnaire (Generic Core, Ukrainian version for respondents aged 13-18 years) was used to assess the quality of life. Participants perception about themselves (self-concept) was studied by the assessment of the physical selfconcept, mood, sports and academic competencies. Dependent nonparametric samples were compared using the Wilcoxon Z-criterion. Results. After participating in the 8-week program, there was an increase $(\mathrm{p}<0,01)$ of the level of physical preparedness by the results of the performance of exercise complexes. The average values of all indicators of the selfconcept increased after participating in the program. Positive dynamics was observed for indicators «Mood» $(\mathrm{p}=0,09)$,

«Sports Competence» $(\mathrm{p}=0,09)$, «Academic Competence» $(\mathrm{p}=0,10)$. At the end of the program, the quality of life indicators increased by 4-10 points and exceeded the value of 75 points. Changes were observed to the indicators of the Physical Functioning Scale $(10 \%, \mathrm{p}=0,1)$, Emotional Functioning Scale $(14 \%, \mathrm{p}=0,09)$ and School Functioning Scale (15\%, p=0,03). Conclusions. Simultaneously with raising in the level of physical preparedness, 8-week CrossFit program was useful for increasing of self-confidence and improving mood. The participants have observed an increase in the quality of life by $10-15 \%$.

Key words: health-related quality of life, mental health; PedsQL, CrossFit, strength fitness, adolescent.

Вступ. Кожний шостий мешканець нашої планети - це особа віком 10-19 років. Цю категорію населення, зазвичай, розглядають як таку, яка має найліпше здоров’я. Проте детальний аналіз захворюваності та підрахунок кількості років, утрачених через інвалідність, виявляють, що порушення здоров’я цієї вікової групи становлять 15 \% від загальної захворюваності у світі. У більшості країн основними причинами захворюваності $\epsilon$ дорожньо-транспортні пригоди, залізодефіцитна анемія, навмисне заподіяння шкоди власному здоров'ю, тривожні та депресивні розлади. У 2015 р. в Європейському регіоні через порушення психічного здоров'я втрачено 1480 років на 100 тис. осіб віком 10 19 років (індекс DAILY), тоді як на анемію й дорожньо-транспортний травматизм припадало 786 i 445 утрачених років відповідно [26]. Низький рівень психічного здоров’я в молодому віці особливо небезпечний, оскільки стає тригером розвитку ризикованої поведінки, різних залежностей, погіршення фізичного стану [9]. Усе це в комплексі й надалі сприяє негативним змінам, які мають довгострокові наслідки та спроможні суттєво погіршити якість життя в дорослому віці.

Спостереження за різними аспектами здоров'я, популяризація здорової поведінки серед молоді важливі не лише для забезпечення ранньої профілактики та втручання, але іє відмінною інвестицією в розвиток та процвітання країни.

Порушення психічного здоров'я $є$ соціально виснажливими, вони безпосередньо пов'язані 3 випадками самогубств, зловживанням наркотичних речовин, бездомністю. Серед дітей та молоді $20 \%$ мають незначні проблеми з психічним здоров'ям, а 7-10\% - тяжкі порушення, що перешкоджають нормальному розвитку [10]. Окрім серйозних випадків, дуже поширені емоційні та депресивні розлади, значна кількість осіб негативно оцінює власну зовнішність і здібності, страждає від хронічного стресу, скаржиться на безнадію та тривогу. Незважаючи на те, що всі ці явища суттєво погіршують якість життя людини, зазвичай їх клінічно не діагностують, а отже, поширеність таких проблем оцінити доволі важко. Доведено, що показники психічного нездоров’я вищі серед осіб жіночої статі й соціально незахищених категорій населення [14].

Незважаючи на напрацьовані рекомендації, добре розроблені протоколи лікування, наявність соціальної стигми перешкоджає зверненню потенційних пацієнтів за допомогою, а це, зі свого боку, вимагає пошуку альтернативних підходів до корекції психічного стану.

Результати наукових досліджень переконують, що саме заняття фізичною культурою та спортом можуть не лише попереджувати проблеми 3 психічним здоров'ям, але й пом'якшувати перебіг цієї групи захворювань. Загалом заняття фізичною культурою та спортом розглядають у чотирьох площинах, зважаючи на їх безпосередній позитивний вплив на психічне здоров'я, - це лікування психічних хвороб і розладів; профілактика психічних захворювань і розладів; покращення психічного та 
фізичного благополуччя осіб із психічними захворюваннями; покращення психічного благополуччя населення в цілому $[2 ; 10 ; 12 ; 18 ; 19 ; 20 ; 22]$. Серед загальних позитивних ефектів науковці називають зростання рівня ендорфінів, мітохондріогенезу, продукування нейромедіаторів, ослаблення реакції гіпоталамо-гіпофізарно-надниркової системи на стрес [13; 16; 25], зменшення запальних процесів [16], підвищення рівня самоефективності тощо $[3 ; 7 ; 15]$.

Незважаючи на значні напрацювання, детальне вивчення біологічних, соціальних і поведінкових аспектів та значення рухової активності для психічного здоров'я людини, науковці визнають, що основний масив накопичених даних стосується дорослого населення. Відкритими для розгляду та дискусії залишаються питання розуміння механізмів впливу фізичної активності на психічне здоров'я дітей та підлітків.

Мета роботи - оцінити вплив занять кросфітом на психічний стан і показники якості життя осіб підліткового віку.

Матеріал і методи дослідження. У дослідженні взяли участь 14 осіб віком 14-16 років. Від усіх учасників отримано інформовану згоду на участь у дослідженні.

Згідно $з$ укладеною програмою, тренування з кросфіту тривалістю 1 год відбувалися тричі на тиждень упродовж двох місяців (загальна кількість занять - 24). До складу тренувань входили багатофункціональні комплексні вправи, переважно силової спрямованості, які учасники виконували в аеробному режимі в зоні високої інтенсивності, тривалістю не більше ніж 20 хв. Основна частина тренувань містила різні комплекси вправ (табл. 1).

Таблиия 1

Комплекси вправ під час тренувань

\begin{tabular}{|c|c|c|}
\hline $\begin{array}{c}\text { Номер } \\
\text { заняття }\end{array}$ & Комплекс вправ основної частини & Протокол \\
\hline 1,13 & $\begin{array}{l}\text { 1-ша хв - } 7 \text { відтискань, 2-га хв - } 10 \text { присідань із гантелями 4-5 кг, 3-тя хв - } \\
100 \text { м біг }\end{array}$ & $\mathrm{EMOM}^{1}, 12 \mathrm{xB}$ \\
\hline 2,14 & $\begin{array}{l}\text { 1-ша хв - присіди, 2-га хв - відпочинок, 3-тя хв - сіт-апи, 4-та хв - від- } \\
\text { починок, 5-та хв - джампінг-джек, 6-та хв - відпочинок }\end{array}$ & $2 \mathrm{RFT}^{2}$ \\
\hline 3,15 & $\begin{array}{l}10 \text { відтискань, } 10 \text { ривків гантелі (3-4 кг), } 5 \text { присідань із гантеллю (5-6 кг), } \\
5 \text { сіт-апів, } 50 \text { м біг }\end{array}$ & RFT \\
\hline 4,16 & $\begin{array}{l}\text { 1-ша хв - } 10 \text { трастерів (2-3 кг), 2-га хв - } 12 \text { сіт-апів, 3-тя хв - } 10 \text { від- } \\
\text { тискань, 4-та хв - } 12 \text { джампінг-джеків }\end{array}$ & EMOM, 12 хв \\
\hline \multirow{2}{*}{5,17} & $\begin{array}{l}\text { 1-ша хв }-8-10 \text { жимів лежачи (10 кг), 2-га хв - } 10 \text { стрибкових підтягувань } \\
\text { iз тумби } 40-50 \text { см }\end{array}$ & EMOM, 8 хв \\
\hline & $\begin{array}{l}10 \text { відтискань від підлоги, } 10 \text { сіт-апів, } 10 \text { присідань та } 30 \text { стрибків на } \\
\text { скакалці }\end{array}$ & 3RFT \\
\hline \multirow[t]{2}{*}{6,18} & $\begin{array}{l}1-3 \text { хв }-8 \text { разів узяття метбола вагою } 4 \text { кг у стійку, } 4-9 \text { хв }-6 \text { разів узяття } \\
\text { метбола вагою 4-6 кг }\end{array}$ & EMOM, 9 хв \\
\hline & 12 гіперекстензій на тренажері GHD, 30 с планка, 1 хв відпочинку & 5RFT \\
\hline \multirow[b]{2}{*}{7,19} & Трастери з гантелями (3-4 кг) & $21-15-9^{3}$ \\
\hline & $\begin{array}{l}\text { Сіт-апи (20 c), кут (10 c), складка (20 c), кут (10 c), виконання макси- } \\
\text { мальної кількості підходів без перерви }\end{array}$ & Табата $^{4}$ \\
\hline 8,20 & $\begin{array}{l}8-10 \text { жимів гантелей (3 кг), } 8-10 \text { разів узяття метбола в стійку (4 кг), } 8- \\
10 \text { разів узяття метбола плюс жим }\end{array}$ & EMOM, 16 хв \\
\hline \multirow[b]{2}{*}{9,21} & Силові присідання з гантеллю (5 підходів по 5 повторень) & \\
\hline & $\begin{array}{l}15 \text { стрибкових підтягувань із тумби } 40-50 \text { см, кут ( } 30 \text { с), } 10 \text { випадів, } \\
10 \text { присідань }\end{array}$ & 3RFT \\
\hline 10,22 & 8-10 махів гирею вагою 8 кг, 10 трастерів (2-3 кг), 30 стрибків на скакалці & EMOM, 12 хв \\
\hline 11,23 & Застрибування на тумбу висотою 40-50 см, ривок гантелі (4-5 кг) & $21-15-9$ \\
\hline 12,24 & $\begin{array}{l}8 \text { бурпі, } 8 \text { кидків метбола вагою } 4 \text { кг, } 12 \text { сіт-апів, } \\
7 \text { відтискань, } 7 \text { трастерів із гантелями вагою } 2 \text { кг, } 7 \text { бурпі }\end{array}$ & EMOM, 12 хв \\
\hline
\end{tabular}

Примітки. ${ }^{1}$ - вправи виконували впродовж визначеного періоду часу; чим швидше учасник виконував поставлене завдання, тим більше часу він мав на відпочинок; якщо для завдання не вистачало відведеного часу, вправу припиняли; ${ }^{2}-$ виконання $\mathrm{n}$ раундів на год; ${ }^{3}-$ у першому заході вправу виконували 21 раз, у другому -15 разів, у третьому - 9; ${ }^{4}-$ максимальна кількість повторів без перерви.

До та після участі в програмі оцінювали рівень фізичної підготовленості учасників, показники якості життя та «Я»-концепцію. 
Для оиінювання рівня фізичної підготовленості використовували комплекси, що складалися 3 таких вправ:

- комплекс № 1 - 10 відтискань, 10 ривків гантелі, п’ять строгих присідань, п’ять сіт-апів, 50 м біг; виконували за протоколом 3RFT, результат вимірювали в секундах;

- комплекс № 2 - трастери, бурпі через гантелю, стрибки зі скакалкою; виконували за протоколом «21-15-9», результат - у секундах;

- комплекс № 3 - 15 стрибкових підтягувань, 15 сіт-апів, 10 випадів, 10 строгих присідань; виконували за протоколом 3RFT, результ вимірювали в секундах;

- комплекс № 4 - сім трастерів, сім строгих підтягувань із фітнес-еспандером, який компенсовує 20-50 кг, сім бурпі; виконували за протоколом ЕМОМ, результат - максимальна кількість раундів, кількість повторень;

- комплекс № 5 - сіт-апи (20 c), кут (10 c), підйоми корпусу до ніг (20 c), кут (10 c); виконували за протоколом табата, результат вимірювали в секундах.

Додаткові дані про рівень фізичної підготовленості отримували за результатами виконання таких вправ: бурпі (максимальна кількість повторень/ хв), стрибки зі скакалкою (максимальна кількість повторень/ хв), присід (максимальна кількість повторень/ хв), трастери (максимальна кількість повторень/ хв), строгі підтягування 3 фітнес-еспандером, який компенсує 20-50 кг (максимальна кількість повторень), строгі відтискання (максимальна кількість повторень), стрибок у довжину (см), стрибок у висоту (см), силові присідання (кг), жим лежачи (кг), жим гантелей сидячи (кг).

Для визначення кількісних показників якості жсття застосовували анкету Pediatric Quality of Life Inventory ${ }^{\mathrm{TM}}$ (PedsQL ${ }^{\mathrm{TM}}$ Generic Core, український варіант для респондентів віком 13-18 років) [23; 24]. На iii використання в дослідженні отримано дозвіл від організації Mapi Research Trust. Анкета складається з 23 запитань, що стосуються щоденної активності та проблем зі здоров’ям упродовж останніх семи днів. Результати підраховували в балах (максимальне значення - 100 , мінімальне - 0) за шкалами «Фізичне функціонування», «Емоційне функціонування», «Соціальне функціонування»,

«Функціонування в школі».

Уявлення учасників про самого себе («Я»-конщепџія), а саме оцінювання фізичного «Я», настрою, спортивної та академічної компетентностей, визначали із застосуванням комплексу позитивних i негативних тверджень, адаптованих із робіт С. Хартер, У. Скіфеле, В. Бретшнайдера та Е. Герлаха [27]. Для цього використовували твердження «Я часто сумую без причини», «Я рідко сміюся», «Я часто сиджу без діла, тому що не хочу нічого робити», «Якщо інші веселяться, я не можу сміятися й веселитися 3 ними», «Я більше нічому не радію і ніщо не приносить мені задоволення»; «У мене $\epsilon$ причина, щоб пишатися собою», «Загалом, я дуже задоволений собою», «Я про себе не дуже високої думки» й т. ін. Емоційний стан респондента під час уроків фізичної культури/ занять спортом використовували як індикатор ставлення до фізичної культури («Якщо хтось згадує про спорт, то в мене всередині все ніби стискається», «Під час уроків/занять фізичною культурою/спортом я забуваю про все», «У вільний час я найбільш охоче займався б фізичною культурою та спортом»тощо).

Спортивну компетентність вивчали за допомогою питань, що стосувалися здатності до певних видів рухової активності, академічну компетентність - за можливостями респондента справлятися 3 шкільними завданнями.

Питання оцінювали за 4-бальною шкалою (максимальне значення - 4, мінімальне значення - 1).

Статистична обробка даних. Визначали середне арифметичне (М), стандартну похибку середнього (SE), найменше й найбільше значення (Xmin, Xmax), медіану (Me), довірчі інтервали (95 \% $\mathrm{Cl})$. Залежні між собою непараметричні вибірки порівнювали за допомогою Z-критерію Вілкоксона. Достовірними вважали відмінності при рівні значимості не нижче ніж $95 \%(\mathrm{p} \leq 0,1)$.

Результати дослідження. Зміни фізичної підготовленості осіб підліткового віку. Після участі у 8тижневій програмі спостерігали статистично достовірне зростання рівня фізичної підготовленості за результатами першого $(\mathrm{p}=0,03)$, другого $(\mathrm{p}=0,02)$ та четвертого $(\mathrm{p}=0,01)$ комплексів (табл. 2$)$.

За даними додаткового оцінювання, поліпшувалися також результати таких вправ: стрибки зі скакалкою $(\mathrm{p}=0,01)$, трастери ( $\mathrm{p}=0,01)$, строгі відтискання $(\mathrm{p}=0,01)$, стрибок у висоту $(\mathrm{p}=0,02)$, силові присідання $(\mathrm{p}<0,001)$, жим лежачи $(\mathrm{p}<0,001)$, жим гантелей сидячи $(\mathrm{p}<0,001)$, підтягування 3 фітнесеспандером $(\mathrm{p}=0,01)$.

Зміни показників «Я»-конщепиії осіб підліткового віку. Середні значення всіх показників «Я»-концепції зростали після участі в програмі (табл. 3). Так, показник «Оцінювання фізичного «Я» 
збільшився на 0,2 бала, «Оцінювання зовнішності» - на 0,1 бала, «Самоповага» - на 0,3 бала, «Настрій» - на 0,2 бала, «Спортивна компетентність» - на 0,2 бала, «Академічна компетентність» - на 0,3 бала, «Ставлення до уроку фізичного виховання» - на 0,1 бала. Позитивну динаміку спостерігали для показників «Настрій» $(\mathrm{p}=0,09)$, «Спортивна компетентність» $(\mathrm{p}=0,09)$, «Академічна компетентність» $(\mathrm{p}=0,10)$.

Таблиия 2

Динаміка фізичної підготовленості осіб підліткового віку

\begin{tabular}{|c|c|c|c|c|c|c|c|c|}
\hline Показник & $\begin{array}{c}\text { До/ } \\
\text { після } \\
\text { про- } \\
\text { грами }\end{array}$ & $\mathbf{M} \pm \mathbf{S E}$ & $95 \% \mathrm{CI}$ & Min & Me & Max & $\mathbf{Z}$ & $\mathbf{p}$ \\
\hline \multirow{2}{*}{ Комплекс $1, c$} & До & $\begin{array}{l}391,1 \\
\pm 4,4\end{array}$ & $\begin{array}{c}381,5 \\
400,6\end{array}$ & 362 & 390 & 419 & \multirow{2}{*}{2,13} & \multirow{2}{*}{$0,03^{*}$} \\
\hline & Після & $\begin{array}{r}379,6 \\
\pm 17,3\end{array}$ & $\begin{array}{c}341,8 \\
417,4\end{array}$ & 213 & 381 & 510 & & \\
\hline \multirow{2}{*}{ Комплекс 2, c } & До & $\begin{array}{l}530,5 \\
\pm 1,9\end{array}$ & $\begin{array}{l}526,4 ; \\
534,6\end{array}$ & 518 & 530 & 542 & \multirow{2}{*}{2,28} & \multirow{2}{*}{$0,02^{*}$} \\
\hline & Після & $\begin{array}{l}521,6 \\
\pm 4,4\end{array}$ & $\begin{array}{l}512,1 ; \\
531,2\end{array}$ & 472 & 523 & 533 & & \\
\hline \multirow{2}{*}{ Комплекс $3, c$} & До & $\begin{array}{l}468,9 \\
\pm 2,6 \\
\end{array}$ & $\begin{array}{r}463,3 ; \\
474,5\end{array}$ & 450 & 470 & 482 & \multirow{2}{*}{1,54} & \multirow{2}{*}{0,12} \\
\hline & Після & $\begin{array}{l}468,0 \\
\pm 5,2 \\
\end{array}$ & $\begin{array}{c}456,7 ; \\
479,3\end{array}$ & 440 & 468 & 520 & & \\
\hline \multirow{2}{*}{$\begin{array}{l}\text { Комплекс 4, } \\
\text { к-сть } \\
\text { повторень }\end{array}$} & До & $\begin{array}{r}30,4 \\
\pm 2,5 \\
\end{array}$ & $\begin{array}{l}24,9 ; \\
35,9\end{array}$ & 19 & 35 & 41 & \multirow{2}{*}{$-2,56$} & \multirow{2}{*}{$0,01^{*}$} \\
\hline & Після & $\begin{array}{l}35,2 \\
\pm 1,5 \\
\end{array}$ & $\begin{array}{l}31,9 ; \\
38,4\end{array}$ & 29 & 37 & 41 & & \\
\hline \multirow{2}{*}{ Комплекс 5, c } & До & $\begin{array}{l}179,3 \\
\pm 7,2 \\
\end{array}$ & $\begin{array}{c}163,6 \\
195,1 \\
\end{array}$ & 120 & 180 & 210 & \multirow{2}{*}{$-1,54$} & \multirow{2}{*}{0,12} \\
\hline & Після & $\begin{array}{r}189,3 \\
\pm 14,4 \\
\end{array}$ & $\begin{array}{l}158,0 ; \\
220,6\end{array}$ & 121 & 202 & 223 & & \\
\hline
\end{tabular}

Примітка. * - статистично достовірні зміни $(\mathrm{p} \leq 0,1)$.

Таблиия 3

Динаміка «Я»-концепції осіб підліткового віку, баліє

\begin{tabular}{|c|c|c|c|c|c|c|c|c|}
\hline Показник & $\begin{array}{c}\text { До/ після } \\
\text { про- } \\
\text { грами }\end{array}$ & $\mathbf{M} \pm \mathbf{S E}$ & $95 \% \mathrm{CI}$ & Min & Me & Max & $\mathbf{Z}$ & $\mathbf{p}$ \\
\hline \multirow{2}{*}{ Фізичне «Я» } & До & $2,9 \pm 0,3$ & 2,$3 ; 3,6$ & 1,0 & 3,3 & 4,0 & \multirow{2}{*}{$-0,31$} & \multirow{2}{*}{0,76} \\
\hline & Після & $3,1 \pm 0,3$ & 2,$5 ; 3,6$ & 1,0 & 3,7 & 4,0 & & \\
\hline \multirow{2}{*}{$\begin{array}{l}\text { Оцінювання } \\
\text { зовнішності }\end{array}$} & До & $2,5 \pm 0,2$ & 2,$0 ; 3,0$ & 1,0 & 2,8 & 3,4 & \multirow{2}{*}{$-0,24$} & \multirow{2}{*}{0,80} \\
\hline & Після & $2,6 \pm 0,2$ & 2,$2 ; 3,1$ & 1,4 & 2,8 & 3,6 & & \\
\hline \multirow{2}{*}{ Самоповага } & До & $2,9 \pm 0,1$ & 2,$7 ; 3,2$ & 2,0 & 3,0 & 3,5 & \multirow{2}{*}{$-1,39$} & \multirow{2}{*}{0,17} \\
\hline & Після & $3,2 \pm 0,1$ & 3,$0 ; 3,4$ & 2,8 & 3,3 & 3,8 & & \\
\hline \multirow{2}{*}{ Настрій } & До & $3,2 \pm 0,1$ & 2,$9 ; 3,5$ & 2,4 & 3,4 & 4,0 & \multirow{2}{*}{$-1,69$} & \multirow{2}{*}{$0,09^{*}$} \\
\hline & Після & $3,4 \pm 0,1$ & 3,$3 ; 3,6$ & 3,0 & 3,4 & 4,0 & & \\
\hline \multirow{2}{*}{$\begin{array}{l}\text { Спортивна } \\
\text { компетентність }\end{array}$} & До & $3,3 \pm 0,1$ & 3,$0 ; 3,6$ & 2,5 & 3,5 & 3,8 & \multirow{2}{*}{$-1,70$} & \multirow{2}{*}{$0,09^{*}$} \\
\hline & Після & $3,5 \pm 0,1$ & 3,$3 ; 3,8$ & 2,7 & 3,7 & 4,0 & & \\
\hline \multirow{2}{*}{$\begin{array}{l}\text { Академічна } \\
\text { компетентність }\end{array}$} & До & $2,8 \pm 0,2$ & 2,$4 ; 3,2$ & 2,0 & 2,7 & 4,0 & \multirow{2}{*}{$-1,65$} & \multirow{2}{*}{$0,10^{*}$} \\
\hline & Після & $3,1 \pm 0,1$ & 2,$8 ; 3,4$ & 2,0 & 3,0 & 4,0 & & \\
\hline \multirow{2}{*}{$\begin{array}{l}\text { Ставлення до } \\
\text { фізичної культури }\end{array}$} & До & $3,1 \pm 0,1$ & 2,$8 ; 3,3$ & 2,3 & 3,2 & 3,7 & \multirow{2}{*}{$-1,02$} & \multirow{2}{*}{0,32} \\
\hline & Після & $3,2 \pm 0,1$ & 2,$8 ; 3,5$ & 2,0 & 3,3 & 3,7 & & \\
\hline
\end{tabular}

Примітка. * - статистично достовірні зміни $(\mathrm{p} \leq 0,1)$.

Зміни якості життя осіб підліткового віку. Початкові значення якості життя в респондентів перебували в середньому діапазоні. За більшістю шкал якість життя не перевищувала 70 балів: «Фізичне 
функціонування» $-69,2 \pm 3,4$ бала, «Емоційне функціонування» $-63,1 \pm 5,5$, «Функціонування в школі» - 66,2 $\pm 4,0$ бала (табл. 4).

Серед опитаних були особи як із дуже низькими (30-50 балів), так і високими (94-100 балів) показниками якості життя, проте в межах кожної шкали розкид даних був незначний, довірчі інтервали всіх шкал, за винятком «Соціальне функціонування» $(95 \% \mathrm{Cl}-66,9-89,3$ бала), перебували в діапазоні середніх значень.

По завершенню 8-тижневої програми показники якості життя зросли на 4-10 балів та перевищували значення 75 балів. Статистично достовірні зміни спостерігали щодо показників шкал «Фізичне функціонування» (на $10 \%, \mathrm{p}=0,1)$, «Емоційне функціонування» (на $14 \%, \mathrm{p}=0,09)$ і «Функціонування в школі» (на $15 \%, \mathrm{p}=0,03)$.

Динаміка показників якості життя (балів)

Таблиия 4

\begin{tabular}{|c|c|c|c|c|c|c|c|c|}
\hline Шкала & $\begin{array}{c}\text { До/ } \\
\text { після } \\
\text { про- } \\
\text { грами }\end{array}$ & $\mathbf{M} \pm \mathbf{S E}$ & $95 \% \mathrm{Cl}$ & $\mathbf{X}_{\min }$ & Me & $\mathbf{X}_{\max }$ & $\mathbf{Z}$ & $\mathbf{p}$ \\
\hline \multirow{2}{*}{$\begin{array}{l}\text { Фізичне } \\
\text { функціонування }\end{array}$} & До & $69,2 \pm 3,4$ & 61,$8 ; 76,7$ & 46,9 & 75,0 & 87,5 & \multirow{2}{*}{$-1,65$} & \multirow{2}{*}{$0,10^{*}$} \\
\hline & Після & $76,2 \pm 2,3$ & 71,$2 ; 81,2$ & 62,5 & 78,1 & 93,8 & & \\
\hline \multirow{2}{*}{$\begin{array}{l}\text { Емоційне } \\
\text { функціонування }\end{array}$} & До & $63,1 \pm 5,5$ & 51,$1 ; 75,0$ & 30,0 & 65,0 & 95,0 & \multirow{2}{*}{$-1,69$} & \multirow{2}{*}{$0,09^{*}$} \\
\hline & Після & $71,9 \pm 4,5$ & 62,$1 ; 81,8$ & 30,0 & 75,0 & 95,0 & & \\
\hline \multirow{2}{*}{$\begin{array}{l}\text { Соціальне } \\
\text { функціонування }\end{array}$} & До & $78,1 \pm 5,1$ & 66,$9 ; 89,3$ & 40,0 & 85,0 & 95,0 & \multirow{2}{*}{$-0,74$} & \multirow{2}{*}{0,47} \\
\hline & Після & $82,7 \pm 5,0$ & 71,$8 ; 93,6$ & 45,0 & 90,0 & 100,0 & & \\
\hline \multirow{2}{*}{$\begin{array}{l}\text { Функціонування } \\
\text { в школі }\end{array}$} & До & $66,2 \pm 4,0$ & 57,$3 ; 75,0$ & 50,0 & 65,0 & 100,0 & \multirow{2}{*}{$-2,15$} & \multirow{2}{*}{$0,03^{*}$} \\
\hline & Після & $76,2 \pm 3,5$ & 68,$4 ; 83,9$ & 60,0 & 75,0 & 100,0 & & \\
\hline
\end{tabular}

Примітка. ${ }^{*}$ - статистично достовірні зміни $(\mathrm{p} \leq 0,1)$.

Дискусія. Тренування за системою кросфіт спрямовані на розвиток витривалості, швидкісних і силових якостей, координації, спритності та балансу. При конструюванні занять використовують елементи різних видів спорту - гімнастики, важкої й легкої атлетики тощо [4]. Заняття містять вправи високої інтенсивності, які потрібно повторювати багаторазово, виконувати швидко, при цьому відновлення між вправами практично відсутнє або мінімальне. Запропонована 8-тижнева програма сприяла підвищенню рівня тренованості, зокрема функціональних здатностей кардіореспіраторної системи, що можна прослідкувати за поліпшенням показників контрольних комплексів вправ. Отримані результати підтверджують дані інших наукових досліджень $[1 ; 6 ; 8]$, зокрема після участі в тренуваннях аналогічної тривалості спостерігали статистично достовірні зміни показника індексу маси тіла й результатів шатл-тесту [6].

Результати, що стосуються поліпшення психічного здоров'я, як результат занять кросфітом $\epsilon$ доволі неоднозначними. У роботі Н. Еазера та ін. [5] не виявлено достовірних змін показників психічного здоров'я в осіб віком 15 років; проте в підгрупі учасників із підвищеним ризиком психічного дистресу, показники поліпшувалися. Відповідно до інших даних тієї ж дослідницької групи [6], в учасників спостерігали абсолютно протилежні результати. Цікавою є думка науковців, згідно з якою тренування за системою кросфіт ефективні для профілактики та лікування вікових змін (наприклад старечих деменцій), оскільки стимулюють процеси нейрогенезу, вироблення білків, які беруть участь у диференціації клітин, що розвиваються в гіпокампі [17].

Позитивні статистично достовірні зміни спостерігали щодо відповідей учасників на питання стосовно здатності до певних видів рухової активності, розуміння власних шкільних здібностей, успішності на уроках, ефективності прикладених зусиль для виконання шкільних завдань. Тренування за системою кросфіт часто пропонують для молоді, яка перебуває в групі ризику, зокрема має низький рівень соціальної підтримки, складні життєві обставини тощо [11]. Зміни, що відбуваються з учасниками, переважно стосуються самооцінки й зростання впевненості у власних силах [21].

Дія фізичних вправ на різні аспекти якості життя, зокрема на соціальне та емоційне функціонування, обгрунтована недостатньо, проте в низці робіт показано, що заняття фізичною культурою й спортом здатні пом'якшити симптоми депресії, сприяти поліпшенню настрою та соціалізації [27]. Після участі в програмі якість життя осіб підліткового віку за шкалами «Фізичне функціонування» (76,2 \pm 2,3 бала), «Функціонування в школі» (76,2 $\pm 3,5$ бала) змінилася з середньої на високу. Такий ефект 
можна розглядати як достовірний, оскільки якість життя, пов'язана зі здоров'ям, не поліпшується 3 віком серед українського населення [27]. Незважаючи на зростання середнього показника якості життя за шкалою «Соціальне функціонування» (оцінювання стосунків з однолітками, порівняння себе 3 ними), ці зміни були статистично недостовірними, що можна пояснити недостатньою тривалістю програми. За даними літератури, позитивні ефекти в психічному та соціальному складниках якості життя спостерігали в учасників 3-12-місячних програм [27].

Висновки. Одночасно зі збільшенням рівня фізичної підготовленості, 8-тижневі тренування 3 кросфіту сприяли зростанню впевненості в собі (за показниками «спортивна та академічна компетентності»), поліпшенню настрою. В учасників програми спостерігали вищу на $10-15 \%$ якість життя за шкалами «Фізичне функціонування», «Емоційне функціонування» та «Функціонування в школі».

Перспективи подальших досліджень полягають у розробленні тренувальних програм для молоді 3 групи ризику.

\section{Джерела та література}

1. Bellar D., Hatchett A., Judge L. W., Breaux M. E., Marcus L. The relationship of aerobic capacity, anaerobic peak power and experience to performance in CrossFit exercise. Biology of Sport. 2015. Vol. 32(4). P. 315-320; https://doi.org/ 10.5604/20831862.1174771

2. Biddle S. Physical activity and mental health: evidence is growing. World Psychiatry: Official Journal of the World Psychiatric Association (WPA). 2016. Vol. 15(2). P. 176-177. https://doi.org/ 10.1002/wps.20331

3. Chen S., Kim Y., Gao Z. The contributing role of physical education in youth's daily physical activity and sedentary behavior. BMC Public Health. 2014. Vol. 14(1). P. 110. https://doi.org/ 10.1186/1471-2458-14-110

4. Claudino J. G., Gabbett T. J., Bourgeois F., Souza H. de S., Miranda R. C., Mezêncio B., ... Serrão, J. C. CrossFit overview: systematic review and meta-analysis. Sports Medicine-Open. 2018. Vol. 4(1). P. 11. https://doi.org/ 10.1186/ s40798-018-0124-5

5. Eather N., Morgan P. J., Lubans D. R. Effects of exercise on mental health outcomes in adolescents: findings from the CrossFit ${ }^{\mathrm{TM}}$ teens randomized controlled trial. Psychology of Sport and Exercise. 2016. Vol. 26. P. 1423. https://doi.org/ 10.1016/J.PSYCHSPORT.2016.05.008

6. Eather N., Morgan P. J., Lubans D. R. Improving health-related fitness in adolescents: the CrossFit Teens ${ }^{\mathrm{TM}}$ randomised controlled trial. Journal of Sports Sciences. 2016. Vol. 34(3). P. 209-223. https://doi.org/ 10.1080/02640414. 2015.1045925

7. Edmunds S., Biggs H., Goldie I. Let's get physical: The impact of physical activity on wellbeing. Mental Health Foundation. 2013. Vol. 38. P. 1-47.

8. Feito Y., Hoffstetter W., Serafini P., Mangine G. Changes in body composition, bone metabolism, strength, and skill-specific performance resulting from 16-weeks of HIFT. PloS One. 2018. Vol. 13(6), e0198324. https://doi.org/ 10.1371/journal.pone.0198324

9. Fibbins H., Ward P. B., Watkins A., Curtis J., Rosenbaum S. Improving the health of mental health staff through exercise interventions: a systematic review. Journal of Mental Health. 2018. Vol. 27(2). P. 184-191. https://doi.org/ 10.1080/09638237.2018.1437614

10. Fox K. R. The influence of physical activity on mental well-being. Public Health Nutrition. 1999. Vol. 2(3a). P. 411-418. https://doi.org/ 10.1017/S1368980099000567

11. Gipson C. M., Campbell N., Malcom N. L. Partnerships between an at-risk youth CrossFit program and local community organizations: focusing on the antecedents to partnership development. Sports (Basel, Switzerland). 2018. Vol. 6(3). https://doi.org/ 10.3390/sports6030100

12. Jayakody K., Gunadasa S., Hosker C. Exercise for anxiety disorders: Systematic review. British Journal of Sports Medicine. 2014. Vol. 48(3). P. 187-196. https://doi.org/ 10.1136/bjsports-2012-091287

13. Lopresti A. L., Hood S. D., Drummond P. D. A review of lifestyle factors that contribute to important pathways associated with major depression: diet, sleep and exercise. Journal of Affective Disorders. 2013. Vol. 148(1). P. 12-27. https://doi.org/ 10.1016/j.jad.2013.01.014

14. Meade T. Dowswell E. Adolescents' health-related quality of life (HRQoL) changes over time: a three year longitudinal study. Health and Quality of Life Outcomes. 2016. Vol. 14, 14. https://doi.org/ 10.1186/s12955-0160415-9

15. Middelkamp J., van Rooijen M., Wolfhagen P., Steenbergen B. The effects of a self-efficacy intervention on exercise behavior of fitness club members in 52 Weeks and long-term relationships of transtheoretical model constructs. Journal of Sports Science \& Medicine. 2017. Vol. 16(2). P. 163-171.

16. Mikkelsen K., Stojanovska L., Polenakovic M., Bosevski M., Apostolopoulos V. Exercise and mental health. Maturitas. 2017. Vol. 106. P. 48-56. https://doi.org/ 10.1016/j.maturitas.2017.09.003

17. Murawska-Cialowicz E., Wojna J., Zuwala-Jagiello J. Crossfit training changes brain-derived neurotrophic factor and irisin levels at rest, after wingate and progressive tests, and improves aerobic capacity and body composition of young physically active men and women. Journal of Physiology and Pharmacology: An Official Journal of the Polish Physiological Society. 2015. Vol. 66(6). P. 811-821. 
18. Pavlova I., Bodnar I., Vitos J. The role of karate in preparing boys for school education. Physical Activity Review. 2018. Vol. 6. https://doi.org/ 10.16926/par.2018.06.08

19. Pavlova I., Vynogradskyi B., Borek Z., Borek I. Life quality and physical activity of Ukrainian residents. Journal of Physical Education and Sport. 2015. Vol. 15(4). P. 809-814. https://doi.org/ 10.7752/jpes.2015.04124

20. Sharma A., Madaan V., Petty F. D. Exercise for mental health. Primary Care Companion to the Journal of Clinical Psychiatry. 2006. Vol. 8(2), 106.

21. Smith J. J., Eather N., Morgan P. J., Plotnikoff R. C., Faigenbaum A. D., Lubans D. R. The health benefits of muscular fitness for children and adolescents: a sytematic review and meta-analysis. Sports Medicine. 2014. Vol. 44(9). P. 1209-1223. https://doi.org/ 10.1007/s40279-014-0196-4

22. Vancampfort D., Van Damme T., Probst M., Firth J., Stubbs B., Basangwa D., Mugisha J. Physical activity is associated with the physical, psychological, social and environmental quality of life in people with mental health problems in a low resource setting. Psychiatry Research. 2017. Vol. 258, 250-254. https://doi.org/ 10.1016/j.psychres. 2017.08.041

23. Varni J. W. Limbers C. A., Burwinkle T. M. Impaired health-related quality of life in children and adolescents with chronic conditions: a comparative analysis of 10 disease clusters and 33 disease categories/severities utilizing the PedsQL 4.0 Generic Core Scales. Health and Quality of Life Outcomes. 2007. Vol. 5. 43. https://doi.org/ 10.1186/1477-7525-5-43

24. Varni J. W., Seid M., Rode C. A. The PedsQL: measurement model for the pediatric quality of life inventory. Medical Care. 1999. Vol. 37(2). P. 126-139.

25. Wipfli B., Landers D., Nagoshi C., Ringenbach S. An examination of serotonin and psychological variables in the relationship between exercise and mental health. Scandinavian Journal of Medicine \& Science in Sports. 2011. Vol. 21(3). P. 474-481. https://doi.org/ 10.1111/j.1600-0838.2009.01049.x

26. World Health Organization. Global Accelerated Action for the Health of Adolescents (AA-HA!) Guidance to Support Country Implementation-Summary. Geneva, 2017. 44 p.

27. Павлова Ю. О. Оздоровчо-рекреаційні технології та якість життя людини: монографія. Львів: ЛДУФК, 2016. $356 \mathrm{c}$.

\section{References}

1. Bellar, D., Hatchett, A., Judge, L. W., Breaux, M. E., \& Marcus, L. (2015). The relationship of aerobic capacity, anaerobic peak power and experience to performance in CrossFit exercise. Biology of Sport, no. 32(4), 315-320. https://doi.org/10.5604/20831862.1174771

2. Biddle, S. (2016). Physical activity and mental health: evidence is growing. World Psychiatry: Official Journal of the World Psychiatric Association (WPA), 15(2), 176-177. https://doi.org/10.1002/wps.20331

3. Chen, S., Kim, Y., \& Gao, Z. (2014). The contributing role of physical education in youth's daily physical activity and sedentary behavior. BMC Public Health, 14(1), 110. https://doi.org/10.1186/1471-2458-14-110

4. Claudino, J. G., Gabbett, T. J., Bourgeois, F., Souza, H. de S., Miranda, R. C., Mezêncio, B., ... Serrão, J. C. (2018). CrossFit overview: systematic review and meta-analysis. Sports Medicine - Open, 4(1), 11. https://doi.org/10.1186/s40798-018-0124-5

5. Eather, N., Morgan, P. J., \& Lubans, D. R. (2016a). Effects of exercise on mental health outcomes in adolescents: findings from the CrossFit ${ }^{\mathrm{TM}}$ teens randomized controlled trial. Psychology of Sport and Exercise, 26, 14-23. https://doi.org/ 10.1016/J.PSYCHSPORT.2016.05.008

6. Eather, N., Morgan, P. J., \& Lubans, D. R. (2016b). Improving health-related fitness in adolescents: the CrossFit Teens $^{\text {TM }}$ randomised controlled trial. Journal of Sports Sciences, 34(3), 209-223. https://doi.org/ 10.1080/02640414.2015.1045925

7. Edmunds, S., Biggs, H., \& Goldie, I. (2013). Let's get physical: The impact of physical activity on wellbeing. Mental Health Foundation, 38, 1-47.

8. Feito, Y., Hoffstetter, W., Serafini, P., \& Mangine, G. (2018). Changes in body composition, bone metabolism, strength, and skill-specific performance resulting from 16-weeks of HIFT. PloS One, 13(6), e0198324. https://doi.org/ 10.1371/journal.pone.0198324

9. Fibbins, H., Ward, P. B., Watkins, A., Curtis, J., \& Rosenbaum, S. (2018). Improving the health of mental health staff through exercise interventions: a systematic review. Journal of Mental Health, 27(2), $184-191$. https://doi.org/ 10.1080/09638237.2018.1437614

10. Fox, K. R. (1999). The influence of physical activity on mental well-being. Public Health Nutrition: 2(3a), 411418. https://doi.org/ 10.1017/S1368980099000567

11. Gipson, C. M., Campbell, N., \& Malcom, N. L. (2018). Partnerships between an at-risk youth CrossFit program and local community organizations: focusing on the antecedents to partnership development. Sports (Basel, Switzerland), 6(3). https://doi.org/ 10.3390/sports6030100

12. Jayakody, K., Gunadasa, S., \& Hosker, C. (2014). Exercise for anxiety disorders: systematic review. British Journal of Sports Medicine, 48(3), 187-196. https://doi.org/ 10.1136/bjsports-2012-091287

13. Lopresti, A. L., Hood, S. D., \& Drummond, P. D. (2013). A review of lifestyle factors that contribute to important pathways associated with major depression: diet, sleep and exercise. Journal of Affective Disorders, 148(1), 1227. https://doi.org/ 10.1016/j.jad.2013.01.014 
14. Meade, T., \& Dowswell, E. (2016). Adolescents' health-related quality of life (HRQoL) changes over time: a three year longitudinal study. Health and Quality of Life Outcomes, 14, 14. https://doi.org/ 10.1186/s12955-0160415-9

15. Middelkamp, J., van Rooijen, M., Wolfhagen, P., \& Steenbergen, B. (2017). The effects of a self-efficacy intervention on exercise behavior of fitness club members in 52 weeks and long-term relationships of transtheoretical model constructs. Journal of Sports Science \& Medicine, 16(2), 163-171.

16. Mikkelsen, K., Stojanovska, L., Polenakovic, M., Bosevski, M., \& Apostolopoulos, V. (2017). Exercise and mental health. Maturitas, 106, 48-56. https://doi.org/ 10.1016/j.maturitas.2017.09.003

17. Murawska-Cialowicz, E., Wojna, J., \& Zuwala-Jagiello, J. (2015). Crossfit training changes brain-derived neurotrophic factor and irisin levels at rest, after wingate and progressive tests, and improves aerobic capacity and body composition of young physically active men and women. Journal of Physiology and Pharmacology: An Official Journal of the Polish Physiological Society, 66(6), 811-821.

18. Pavlova, I., Bodnar, I., \& Vitos, J. (2018). The role of karate in preparing boys for school education. Physical Activity Review, 6. https://doi.org/ 10.16926/par.2018.06.08

19. Pavlova, I., Vynogradskyi, B., Borek, Z., \& Borek, I. (2015). Life quality and physical activity of Ukrainian residents. Journal of Physical Education and Sport ${ }^{\circledR}$ (JPES), 15(4), 809-814. https://doi.org/ 10.7752/jpes.2015.04124

20. Sharma, A., Madaan, V., \& Petty, F. D. (2006). Exercise for mental health. Primary Care Companion to the Journal of Clinical Psychiatry, 8(2), 106.

21. Smith, J. J., Eather, N., Morgan, P. J., Plotnikoff, R. C., Faigenbaum, A. D., \& Lubans, D. R. (2014). The Health Benefits of Muscular Fitness for Children and Adolescents: A Systematic Review and Meta-Analysis. Sports Medicine, 44(9), 1209-1223. https://doi.org/ 10.1007/s40279-014-0196-4

22. Vancampfort, D., Van Damme, T., Probst, M., Firth, J., Stubbs, B., Basangwa, D., \& Mugisha, J. (2017). Physical activity is associated with the physical, psychological, social and environmental quality of life in people with mental health problems in a low resource setting. Psychiatry Research, 258, 250-254. https://doi.org/ 10.1016/j.psychres.2017.08.041

23. Varni, J. W., Limbers, C. A., \& Burwinkle, T. M. (2007). Impaired health-related quality of life in children and adolescents with chronic conditions: a comparative analysis of 10 disease clusters and 33 disease categories/severities utilizing the PedsQL 4.0 Generic Core Scales. Health and Quality of Life Outcomes, 5, 43. https://doi.org/ 10.1186/1477-7525-5-43

24. Varni, J. W., Seid, M., \& Rode, C. A. (1999). The PedsQL: measurement model for the pediatric quality of life inventory. Medical Care, 37(2), 126-139.

25. Wipfli, B., Landers, D., Nagoshi, C., \& Ringenbach, S. (2011). An examination of serotonin and psychological variables in the relationship between exercise and mental health. Scandinavian Journal of Medicine \& Science in Sports, 21(3), 474-481. https://doi.org/ 10.1111/j.1600-0838.2009.01049.x

26. World Health Organization. (2017). Global Accelerated Action for the Health of Adolescents (AA-HA!) Guidance to Support Country Implementation-Summary. Geneva.

27. Pavlova, Iu. (2016). Ozdorovcho-rekreacijni texnologiyi ta yakist` zhy`ttya lyudy`ny`Health-enhancing technologies and quality of human life]. Lviv: LSUPC.

Стаття надійшла до редакції 21.03.2019 р. 